\title{
Preparation of Nano Bioactive Silica from Silica Gel
}

\author{
Sahar M.El-Khouli and Doaa M. El -Mekkawi \\ Physical Chemistry Department, National Research Center, \\ Cairo, Egypt.
}

\begin{abstract}
R IOACTIVE silica was prepared by precipitation of the gel by acid from sodium silicate in the presence of ethylene glycol. The formed gel was homogeneously mixed with calcium carbonate powder. The produced solid was heated at $500^{\circ} \mathrm{C}$ for $3 \mathrm{hr}$ and the calcined material was treated with dilute hydrochloric acid to remove the carbonate. The investigation by X-ray showed that the produced solid before treatment contains amorphous silica with crystalline calcium carbonate phase. The treatment with $\mathrm{HCl}$ removed the crystalline calcium carbonate leaving pure amorphous silica in nanosized particles as confirmed by SEM. The bioactivity of the obtained silica was performed by soaking it in simulative body fluid (SBF) for two weeks followed by investigation using SEM, IR and EDX.
\end{abstract}

Keywords: Bioactive silica, Calcium carbonate, Nano silica and Hydroxyapatite.

Silica gel was in existence as early as the 1640 s as a scientific curiosity. It was used in World War I for the absorption of vapors and gases in gas mask canisters. In World War II, silica gel was indispensable in the war effort for keeping penicillin dry, protecting military equipment from moisture damage.

In chemistry, silica gel is used in chromatography as a stationary phase. In column chromatography, the stationary phase is most often composed of silica gel particles. The hydroxyl $(\mathrm{OH})$ groups on the surface of silica can be functionalized to afford specialty silica gels that exhibit unique stationary phase parameters. These so-called functionalized silica gels are also used in organic synthesis and purification as insoluble reagents and scavengers.

The development of composites has been recognized as a promising strategy to fulfill the complex requirements of biomaterials. This new bioactive nanocoating enhances the effectiveness and improves the long term stability of orthopaedic dental implants. The work nanocoating, as it is referred to, is functionally graded from metal through oxides, silicates, silica, hydroxyl groups and hydroxyapatite (HA). The arrangement and integration of the layers enable the great bonding strength of the layer, and bioactivity is achieved by high silanol (hydroxyl) and HA content. The layer of bioactive silica is exceptionally hard and biologically active. Its hardness resists the formation of wear particles 
and the high silanol and negative surface charge promote strong and rapid bonding to bone.

Bioactive glass and glass-ceramic have been developed for the tissue repairing from the discovery of bioglass and some of them are already clinically used. Since that, many attentions have been focused on designing of glass, glassceramics as well as organic/inorganic composites. It was well known that artificial materials have to form bonelike-apatite on their surfaces in the body environment, because the bioactive glass and glass-ceramics bond to livening bone through the bonelike apatite formed on their surface when implanted into the bone. As a bioactive component ${ }^{(1)}$, it has been proposed that the $\mathrm{Ca}-\mathrm{SiO} 2$ system can be good basic composition of bioactive glass-ceramics; since the dissolved $\mathrm{Ca}$ ion increases the degree of super saturation with respect to apatite and hydrated silica developed on them induce apatite formation when implanted into body environment.

Li et al. ${ }^{(2)}$ proposed that the high concentration of $\mathrm{SiOH}$ groups on the sample surface could promote hydroxyl carbonated apatite nucleation. On the other hand, the surface microstructure of the silica-gel samples has also been related to in vitro bioactivity.

The aim of the work is to prepare nano bioactive silica using simple materials such as sodium silicate (commercial) and calcium carbonate (calcite). The product will be characterized by XRD, IR, SEM, EDX and soaking in SBF to follow up the formation of hydroxyapatite on the surface of the bioactive silica.

\section{Experimental}

\section{Materials of Bioactive Silice}

In this work sodium silicate solution $43 \%$ is used as starting material. Ethylene glycol, Hydrochloric acid and SBF were also used.

\section{Preparation of bioactive silica}

Silica gel was precipitated by using dilute hydrochloric acid solution in the presence of ethylene glycol (10\%). The precipitate was filtered, washed, dried and calcined at $550^{\circ} \mathrm{C}$ for $3 \mathrm{hr}$. Another quantity of silica gel was also prepared in the same manner but the precipitate, after filtration, was mixed with $5 \%$ by weight calcium carbonate powder (1-5micron). The mixture was homogeneously mixed, dried and calcined at $550^{\circ} \mathrm{C}$ for $3 \mathrm{hr}$. The calcined solid with calcium carbonate was treated with dilute hydrochloric acid to remove the calcium carbonate and washed. Finally the solids were characterized.

Egypt. J. Chem. 55, No. 4 (2012) 
Preparation of simulated body fluid (SBF)

The following reagents have to be stocked in a desiccator. Deionized water and distilled water were used for the preparation of SBF:

(1) Sodium chloride $(\mathrm{NaCl})$,

(2) Sodium hydrogen carbonate $\left(\mathrm{NaHCO}_{3}\right)$,

(3) Potassium chloride $(\mathrm{KCl})$,

(4) Di-potassium hydrogen phosphate trihydrate $\left(\mathrm{K}_{2} \mathrm{HPO}_{4} 3 \mathrm{H}_{2} \mathrm{O}\right)$.

(5) Magnesium chloride hexahydrate $\left(\mathrm{MgCl}_{2} \cdot 6 \mathrm{H}_{2} \mathrm{O}\right)$,

(6) Calcium chloride $\left(\mathrm{CaCl}_{2}\right)$,

(7) Sodium sulfate $\left(\mathrm{Na}_{2} \mathrm{SO}_{4}\right)$,

(8) Tris-hydroxymethyl aminomethane: $\left(\left(\mathrm{HOCH}_{2}\right)_{3} \mathrm{CNH}_{2}\right)$ (Tris)

(9) $1 \mathrm{M}(\mathrm{mol} / \mathrm{l})$ Hydrochloric Acid.

(10) $\mathrm{pH}$ standard solutions ( $\mathrm{pH} \mathrm{4,} 7$ and 9).

Ion concentrations of SBF

TABLE . 1. The ion concentrations of SBF are given in Table 1.

\begin{tabular}{|c|c|c|}
\hline \multirow{2}{*}{ Ion } & \multicolumn{2}{|c|}{ Ion concentrations $(\mathrm{mM})$} \\
\cline { 2 - 3 } & Blood plasma & SBF \\
\hline $\mathrm{Na}^{+}$ & 142.0 & 142.0 \\
$\mathrm{~K}^{+}$ & 5.0 & 5.0 \\
$\mathrm{Mg}^{2+}$ & 1.5 & 1.5 \\
$\mathrm{Ca}^{2+}$ & 2.5 & 2.5 \\
$\mathrm{Cl}^{-}$ & 103.0 & 147.8 \\
$\mathrm{HCO}_{3}^{-}$ & 27.0 & 4.2 \\
$\mathrm{HPO}_{4}^{2-}$ & 1.0 & 1.0 \\
$\mathrm{SO}_{4}{ }^{2-}$ & 0.5 & 0.5 \\
$\mathrm{pH}^{2-}$ & $7.2-7.4$ & 7.40 \\
\hline
\end{tabular}

Egypt. J. Chem. 55, No. 4 (2012) 


\section{Materials characterization}

X-ray diffraction patterns were obtained at room temperature using A Philips X-ray diffractometer (Goniometer PW 1050/50) Co Ka radiation $(\lambda=1.78897 \AA$ ), employing cobalt radiation as the $\mathrm{X}$-ray source. The $\mathrm{X}$-ray tube was operated at $36 \mathrm{KV}$ and $16 \mathrm{~mA}$, the samples were packed into a plastic holder, no adhesive or binder was necessary. Spectra were scanned at a rate $2^{\circ} \mathrm{min}^{-1}$ in $4 \theta$.

Scanning electron microscope (SEM) with EDX

The scanning electron microscope (SEM) and Energy dispersive X-rays (EDX) photographs were carried out using SEM Model Philips XL 30 attached with EDX unit، with accelerating voltage $30 \mathrm{k} . \mathrm{V}$. , magnification 10x up to 400.000x and resolution for W. $(3.5 \mathrm{~nm})$. The samples were coated with carbon for both EDX and SEM assessment.

\section{Infrared spectroscopy $(I R)$}

The infrared spectroscopy is a very sensitive technique which can be used effectively to identify the bioactivity of the prepared silica samples by detection of the functional groups. The infrared spectroscopy was carried out using Nexus 670 IR Reflectance and Transmittance spectrometer-Company: Nicolet -Country: USA -Range: $4000-400 \mathrm{~cm}^{-1}$-Resolution: $4 \mathrm{~cm}^{-1}$.

\section{Results and Discussion}

Figures 1-4 show XRD-analyses of the pure calcium carbonate, calcined pure silica, silica-calcium carbonate and silica calcium carbonate after removing of calcium carbonate. From these figures . it can be observed that the prepared silica and silica after removing calcium carbonate were amorphous. The silicacalcium carbonate solid showed two phases, a crystalline calcium carbonate phase and amorphous silica phase. This means that the combination of amorphous silica with crystalline calcium carbonate gave a composite with two different phases. The removal of the crystalline calcium carbonate from the calcined sample leaves pure amorphous silica.

Egypt. J. Chem. 55, No. 4 (2012) 


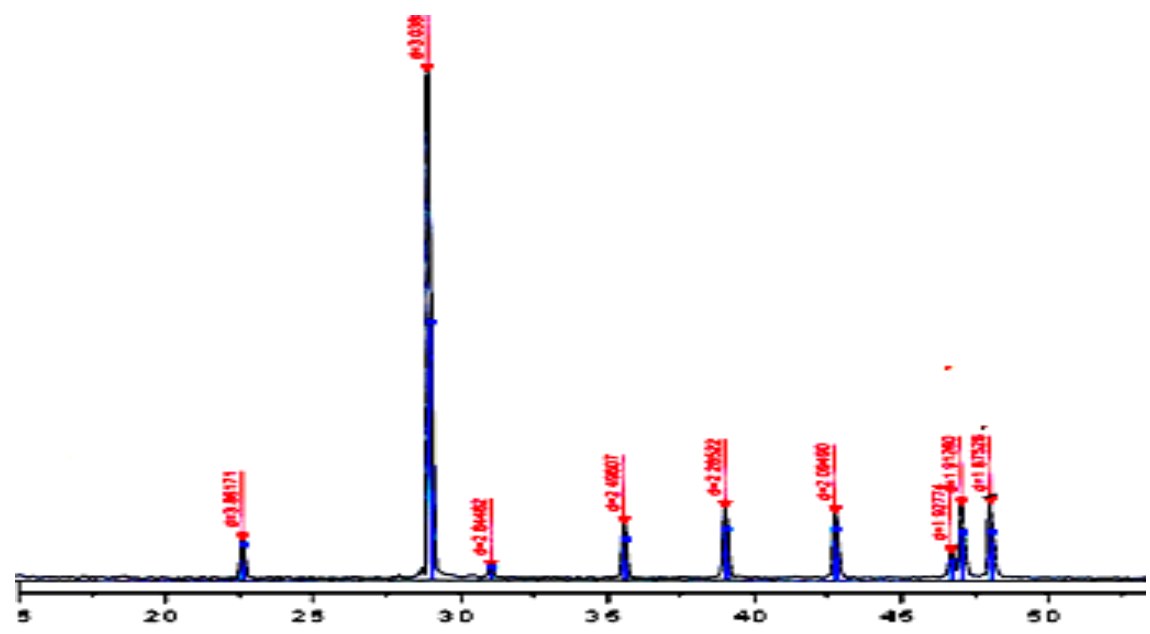

Fig. 1. XRD- of pure calcium carbonate.

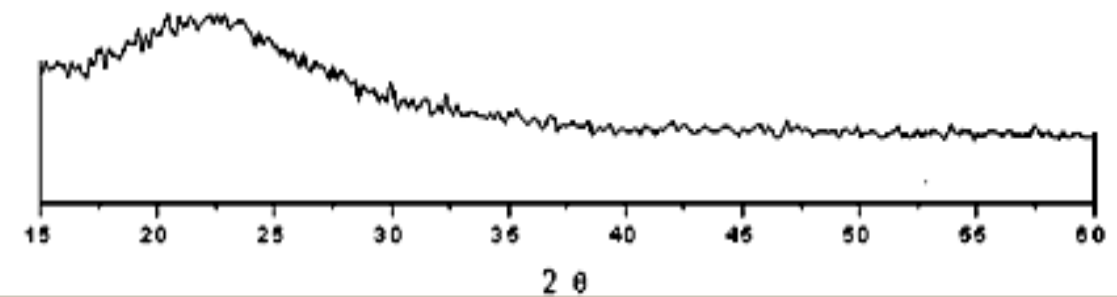

Fig. 2. XRD- of pure silica gel.

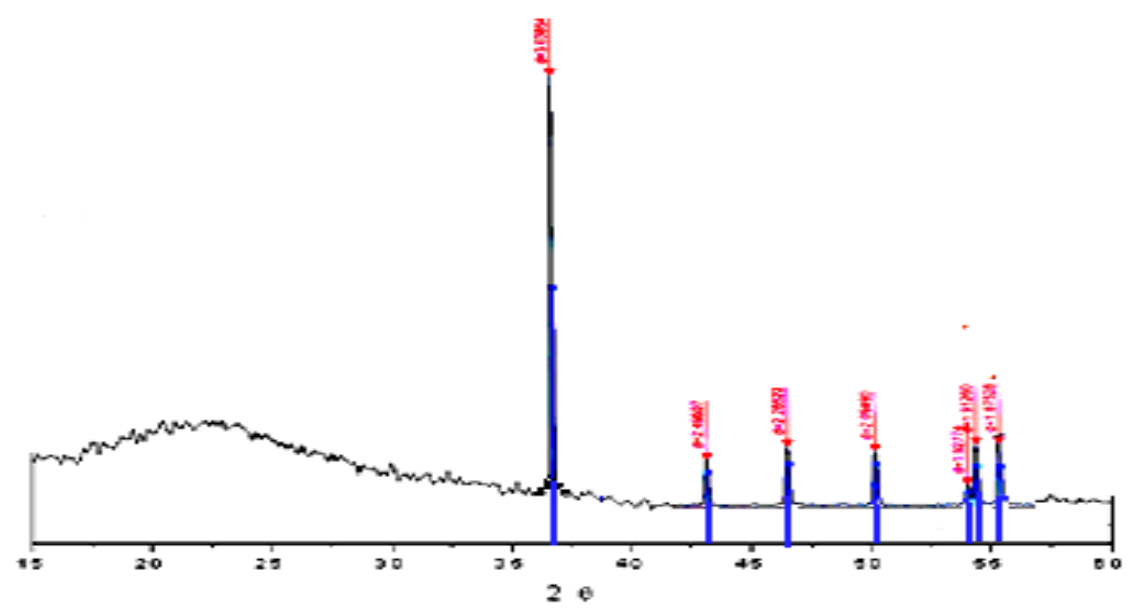

Fig. 3. XRD- of composite of silica gel with calcium carbonate .

Egypt. J. Chem. 55, No. 4 (2012) 


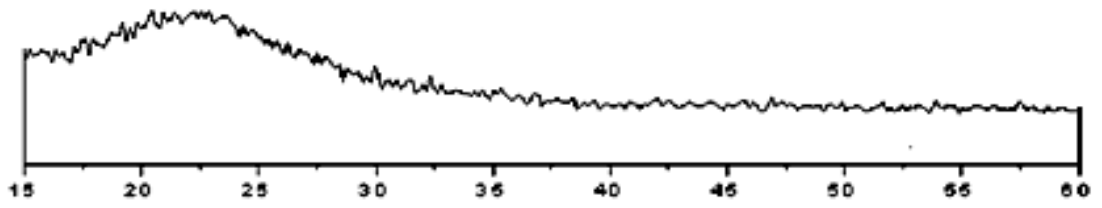

Fig. 4. XRD- of composite of silica gel after removal of calcium carbonate.

\section{SEM-results}

Figure 5 shows that the pure silica is particles with smooth surface. The treatment with calcium carbonate gave roughness to the silica surface (see Fig. 6).

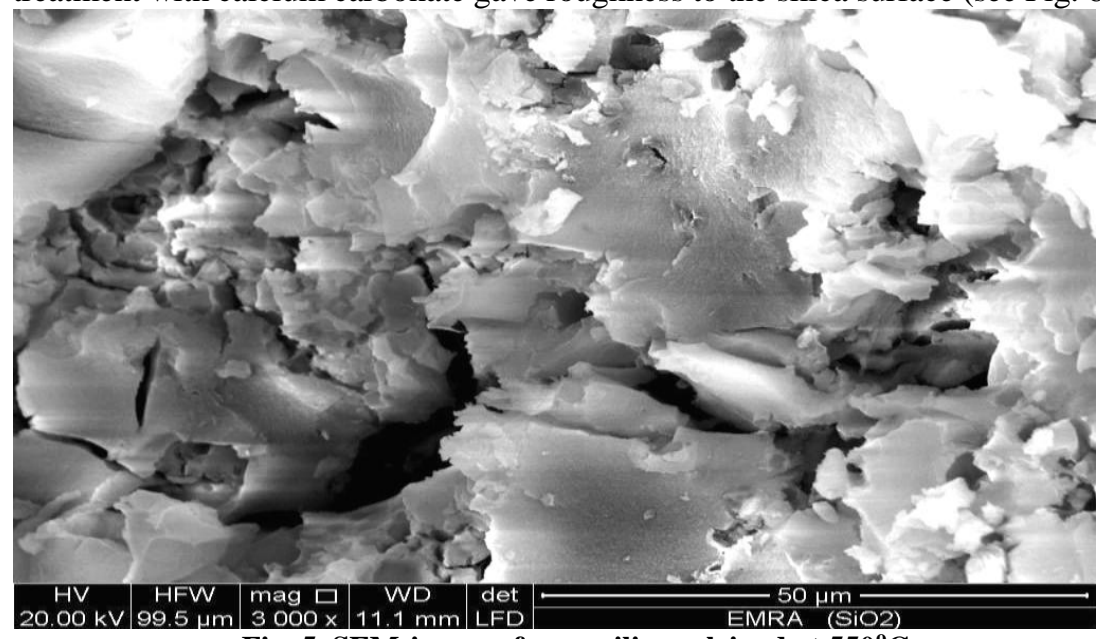

Fig. 5. SEM-image of pure silica calcined at $550^{\circ} \mathrm{C}$.

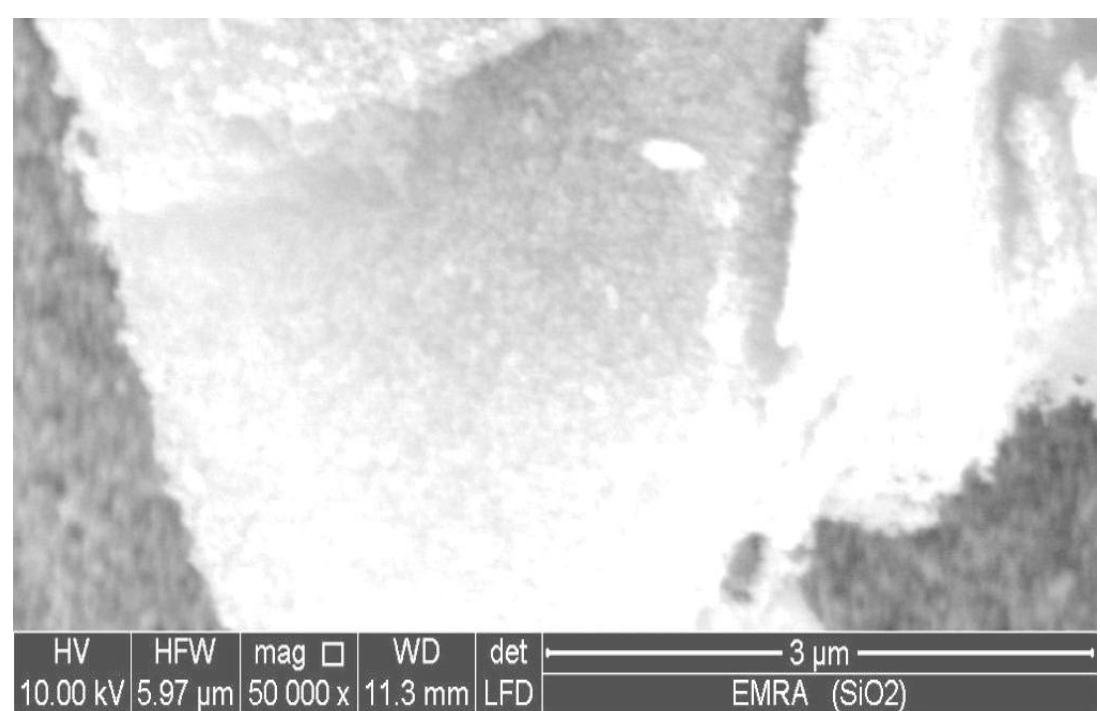

Fig. 6. SEM-image of silica with calcium carbonate calcined at $550^{\circ} \mathrm{C}$.

Egypt. J. Chem. 55, No. 4 (2012) 
After the treatment with $\mathrm{HCl}$, spherical particles with diameter ranging from 45-150 $\mathrm{nm}$ appeared in the SEM- image(Fig.7). These spheres were formed as a result of the dissolution of calcium carbonate from the composite.

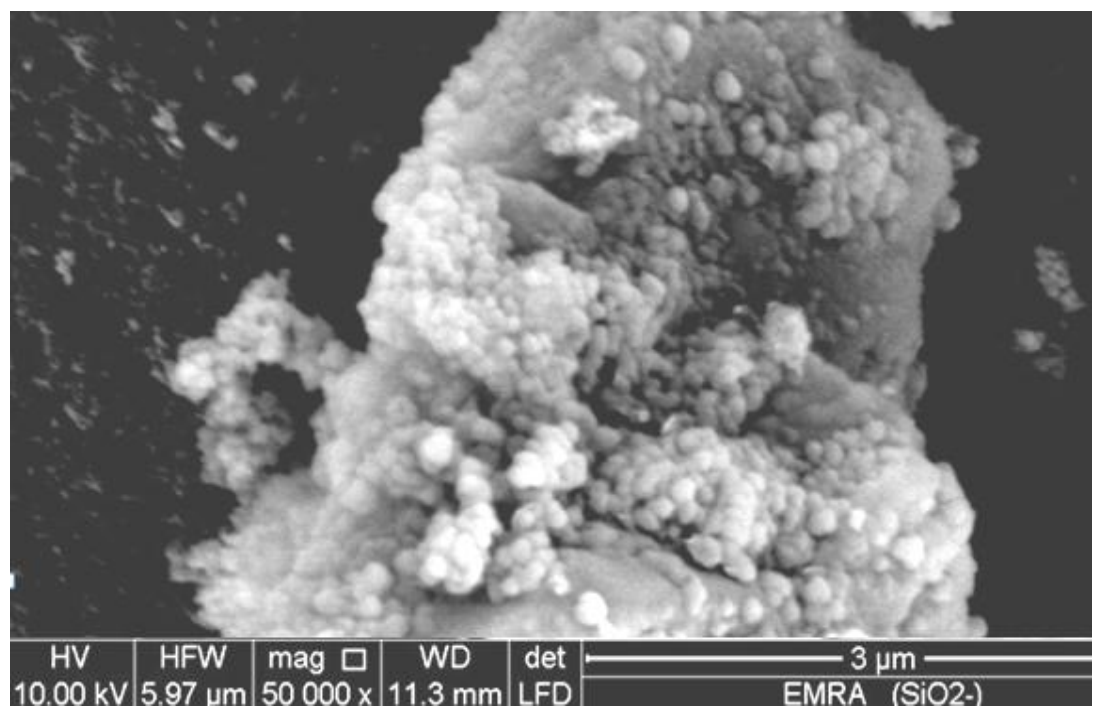

Fig. 7. SEM-image of silica nanoparticles treated with $\mathrm{HCl}$ and calcined at $550^{\circ} \mathrm{C}$.

SEM images also show the morphology of Apatite (AP) layer formed on silica sample after two weeks of soaking in SBF (Fig. 8). The granules appear covered by a dense layer of closely packed particles or forming a thin layer composed of a Ca-P phase. These findings suggest the growth of preformed APprecipitates during the soaking in $\mathrm{SBF}$.

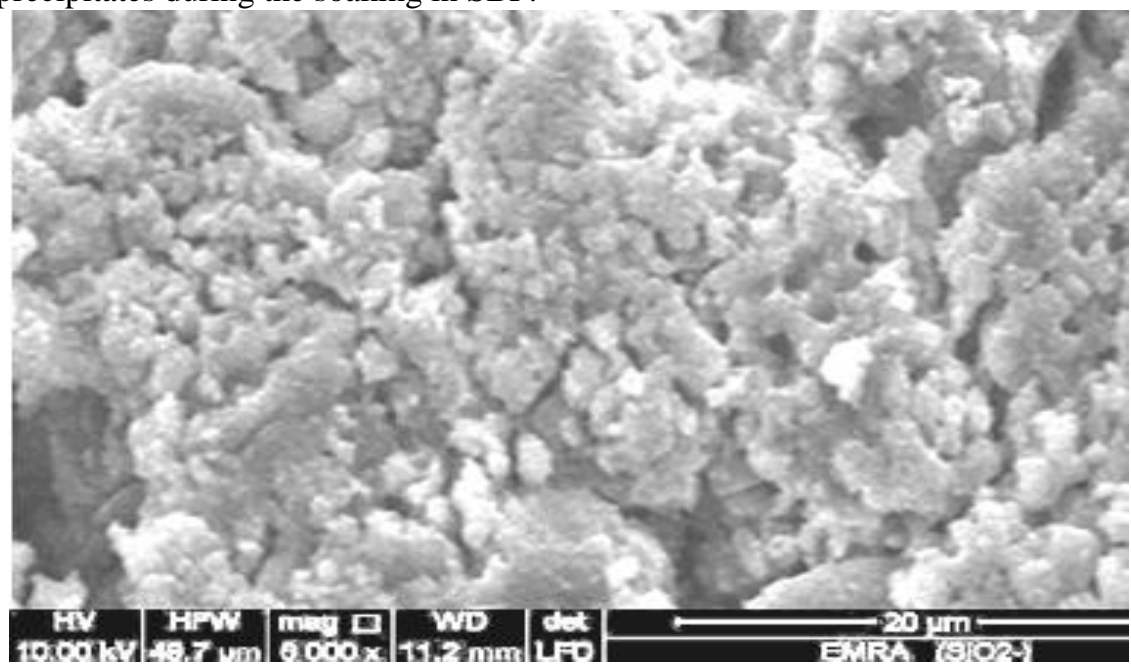

Fig. 8. SEM image shows the morphology of Apatite (AP) layer formed on silica sample after two weeks of soaking in SBF. 
The IR spectra (Fig. 9a) shows well polymerized silica as indicated by the sharpness of the strong $\mathrm{Si}-\mathrm{O}-\mathrm{Si}$ bands, i.e. $\mathrm{Si}-\mathrm{O}-\mathrm{Si}$ bending at $465 \mathrm{~cm}^{-1}$ and $\mathrm{Si}-$ $\mathrm{O}-\mathrm{Si}$ asymmetric stretching at 1088 and $1246 \mathrm{~cm}^{-1(3)}$. Other silica network bands were located at 560,790 , and $970 \mathrm{~cm}^{-1}$. The $560 \mathrm{~cm}^{-1}$ bands are associated with $\mathrm{Si}-$ $\mathrm{O}-\mathrm{Si}$ bending of three- or four member rings (cyclic tri- and tetrasiloxanes) ${ }^{(3-8)}$. The 790 and $970 \mathrm{~cm}^{-1}$ bands are usually assigned to symmetric $\mathrm{Si}-\mathrm{O}-\mathrm{Si}$ stretching and $\mathrm{Si}-\mathrm{OH}$ stretching, respectively ${ }^{(10)}$. The broad band at $3400 \mathrm{~cm}^{-1}$ is associated with H-bonded Si-OH stretching vibrations and H-bonded water ${ }^{(9-12)}$. The band at 3600 $\mathrm{cm}^{-1}$ could be assigned to isolate $\mathrm{Si}-\mathrm{OH}$ stretching ${ }^{(13-15)}$.

(Figure. 9b ) shows the results of IR spectra of the under investigated silica powder prepared by the above mentioned method after soaking in SBF for 2 weeks. The results of bioactivity are in agreement with the results in the literatures ${ }^{(16,17)}$. Also, the bioactivity results obtained showed that the bone like -apatite layer early formed on the surface of the silica. This layer is important to enhance bone forming in vivo.

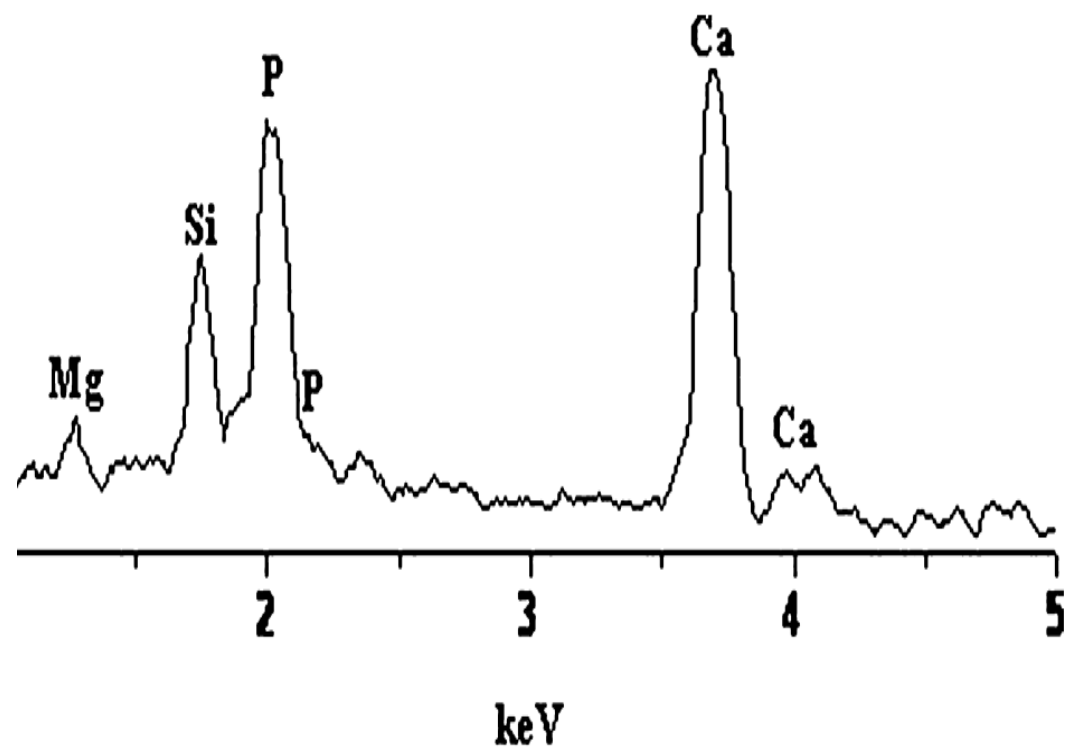

Fig. 9. EDX-spectrum of $\mathrm{SiO}_{2}$ nanoparticles after 14 days soaking in $\mathrm{SBF}$.

Kokubo $^{(3)}$ suggested that for the bioactive silica forming surface silanols upon hydration, a silica layer is produced by exchange of ions in the SBF, and that this layer acts as a nucleation agent for apatite crystal formation. Once the apatite crystals are formed، they grow by consuming calcium and phosphate ions from the SBF. In addition, the filler dissolution rate is important, since the faster the dissolution rate is the faster the ions come into contact with the SBF solution, promoting the surface formation of apatite. In order for bioactive silica to bond to bone, a series of reactions must take place that includes dissolution, precipitation and ion exchange.

Egypt. J. Chem. 55, No. 4 (2012) 
The energy dispersive X-ray analysis (EDX) results for bioactive silica surface after in- vitro show the changes in $\mathrm{Ca}, \mathrm{P}$ and $\mathrm{Si}$ at different immersion periods (Fig. 10). The ratio of calcium to phosphorus shows a decreasing trend as a function of exposure time. The EDX data from selected areas of silica also showed different values of the $\mathrm{Ca} / \mathrm{P}$ ratio (Fig .10).

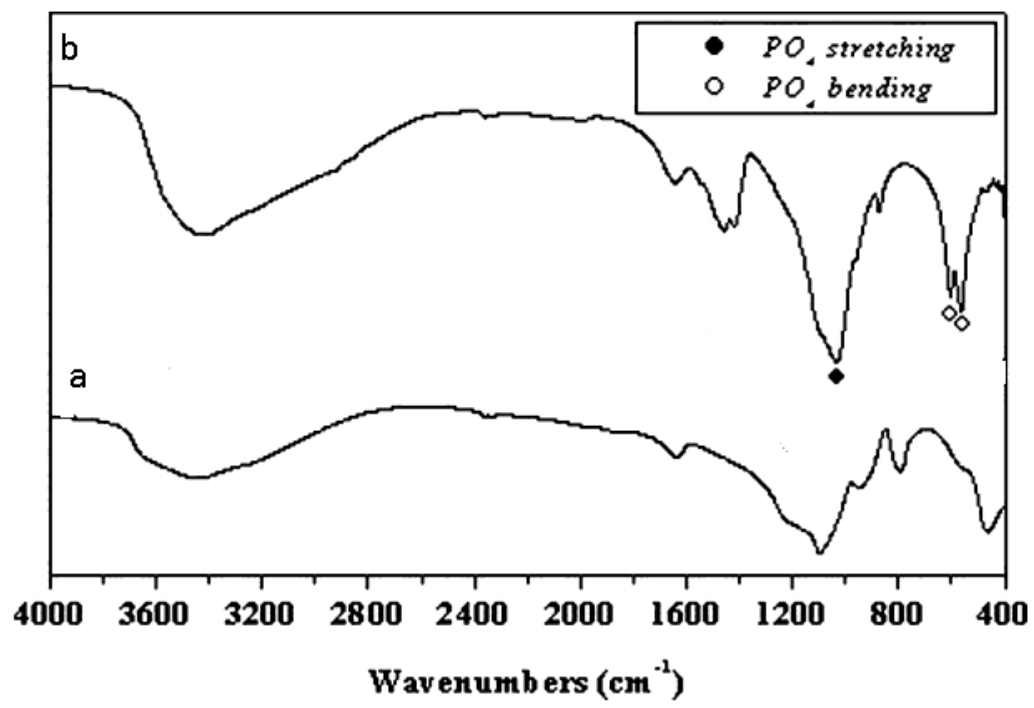

Fig. 10. IR spectra of $\mathrm{SiO}_{2}$ (a) as-prepared; (b) after 14 days soaking in SBF.

Bioactivity

HCA layer formation on the surface of the bioactive materials has shown that reactions occur on the material side in five stages. These stages are the fastest for the highest level of bioactivity. Surface reaction stages I-V on a bioactive glass in aqueous solution are summarized below.

Stage (I): Rapid exchange of $\mathrm{Na}^{+}$or $\mathrm{K}^{+}$with $\mathrm{H}^{+}$or $\mathrm{H}_{3} \mathrm{O}^{+}$from solution.

$$
\mathrm{Si}-\mathrm{O}-\mathrm{Na}^{+}+\mathrm{H}^{+}+\mathrm{OH}^{-} \rightarrow \mathrm{Si}-\mathrm{OH}+\mathrm{Na}^{+}{ }_{\text {(solution) }}+\mathrm{OH}^{-}
$$

Stage (II): Loss of soluble silica in the form of $\mathrm{Si}(\mathrm{OH})_{4}$ to the solution resulting from breakage of $\mathrm{Si}-\mathrm{O}-\mathrm{Si}$ bonds and formation of $\mathrm{Si}-\mathrm{OH}$ (silanols) at the glass solution interface :

$$
2(\mathrm{Si}-\mathrm{O}-\mathrm{Si})+\left(\mathrm{H}_{2} \mathrm{O}\right) \rightarrow 2 \mathrm{Si}-\mathrm{OH}+2 \mathrm{OH}-\mathrm{Si}
$$

Stage (III): Condensation and repolymerization of a $\mathrm{SiO}_{2}$ rich layer on the surface that is depleted in alkalis and alkaline earth cations.

$$
2(\mathrm{Si}-\mathrm{OH})+2(\mathrm{OH}-\mathrm{Si}) \rightarrow \mathrm{Si}-\mathrm{O}-\mathrm{Si}-\mathrm{O}-\mathrm{Si}-\mathrm{O}+\mathrm{H}_{2} \mathrm{O}
$$


Stage (IV) : Migration of $\mathrm{Ca}^{2+}$ and $\mathrm{PO}^{3-}{ }_{4}$ groups from the SBF to the surface through the $\mathrm{SiO}_{2}$-rich layer forming a $\mathrm{CaO}-\mathrm{P}_{2} \mathrm{O}_{5}$-rich film on top of the $\mathrm{SiO}_{2}$-rich layer, followed by growth of an amorphous $\mathrm{CaO}-\mathrm{P}_{2} \mathrm{O}_{5}$-rich film by incorporation of soluble calcium and phosphate from solution.

Stage (V): Crystallization of the amorphous $\mathrm{CaO}-\mathrm{P}_{2} \mathrm{O}_{5}$ film by incorporation of $\mathrm{OH}, \mathrm{CO}_{3}^{2-}$, or $\mathrm{F}$ anions from solution to form a mixed HCA layer.

Concerning the mechanism of the apatite formation on the surfaces of bioactive glasses and glass-ceramics, it has been proposed that hydrated silica developed on their surfaces in the body induces nucleation of the apatite.

These results suggest that the silanols group formed on the surface of the silica gel in the SBF could be responsible for the apatite nucleation. On the other side, recently West et $a l .^{(8)}$ proposed that on the bases of molecular orbital calculation, only the silanol group forming trigonal siloxane can induce the apatite nucleation. However, this has been proved experimentally ${ }^{(3)}$.

\section{Conclusions}

1- Silica gel was prepared by acidification of a solution of commercial sodium silicate.

2- The prepared silica gel was homogeneously mixed with calcium carbonate and heated at $550{ }^{\circ} \mathrm{C}$.

3- The calcium carbonate in the produced composite was leached by hydrochloric acid.

4- The formed silica was examined by soaking it in simulated body fluid for two weeks and it showed good bioactivity as confirmed by EDX and IR.

5- The obtained bioactivity of silica can be attributed to the presence of some ions of calcium in the silica as cited in literature.

\section{References}

1. Li., J.X., Wang, J., Shen, L.R., Xu, Z.J. , L I. P ., Wan, G.J. and Huang, N., The influence of polyethylene terephthalate surfaces modified by silver ion implantation on bacterial adhesion behavior. Surface \& Coatings Technology, 201, 81558159 (2007).

2. Cho, S.B., Kim, S.B., Cho, K.J. Kim, Y.J., Lee, T.H. and Hwang, Y., Control of bioactivity for silica gel by simple surface modification with calcium ion. Key Engineering Materials, 240-242, 93-96 (2003)

Egypt. J. Chem. 55, No. 4 (2012) 
3. Kokubo, T., Bioactive glass ceramics: Properties and applications. J. Biomaterials, 27, 2907- 2915 (2006).

4. Hench, L.L., Bioceramics: Material Characteristics Versus in Vivo Behavior, Vol. 523. New York: The New York Academy of Science: 54-7 I (1988).

5. Ohtsuki, C., Kokubo, T. and Yamamuro, T., Mechanism of apatite formation on CaO-Si02-P205 glasses in a simulated body fluid. J. Non-Cryst. Solids, 143, 84-92 (1992).

6. Ohtsuki, Li, P. C. and Kokubo, T., et al., Apatite formation induced by silica gel in a simulated body fluid. J. Am. Ceram. Soc. 75, 2094-2097 (1992).

7. Nakanishi, Cho., S.B., K. and Kokubo, T. et al., Dependence of apatite formation on silica gel on its structure: Effect of heat treatment. J. Am. Ceram. SOC. 78, 17691774 (1995).

8. West, J.H., Hench, L.L., Yamamuro, T., Kokubo, T. and Nakamura, T., Reaction kinetics of bioactive ceramics part V: Molecular orbital modeling of bioactive glass surface reactions, Kyoto, Japan: Kobunshi Kankokai , 5 (1), 75-86 (1999).

9. Meier W.M. and Olson D.H., Atlas of Zeolite Structure Types, ButterworthHeinemann, London (1992).

10. Uchida M., Antimicrobial zeolite and its application, J. Chem. Ind. 46, 48-54 (1995).

11. Uchida, M., Maru, N., Furuhata, M., Fujino, A., Muramoto, S., Ishibashi, A., Koshiba, K., Shiba, T. and Kikuchi, T., Anti-bacterial zeolite balloon catheter and its potential for urinary tract infection control. Acta Urol. Jpn. 38, 973-8 (1992).

12. Hotta, M., Nakajima, H., Yamamoto, K. and Aono, M., Antibacterial temporary filling materials: The effect of adding various ratios of $\mathrm{Ag}-\mathrm{Zn}$ zeolite. J. Oral Rehabil, 25, 485-9 (1998).

13. Morishita, M., Miyagi, M., Yamasaki, Y., Tsuruda, K., Kawahara, K. and Iwamoto, Y., Study on the effect of mouthrinse containing silver-zeolite on plaque formation. $J$. Clin. Dent. 9, 94-6 (1998). 
14. McGhee, J.R., Michalek, S.M. and Cassell, G.H., The Anaerobic Bacteria Dental Microbiology, Philadelphia: Harper \& Row, p. 450-60 (1982).

15. Kawahara, K., Tsuruda, K., Morishita, M. and Uchida, M., Antibacterial effect of silver-zeolite on oral bacteria under anaerobic condition. J. Dental Materials, 16, 452455 (2000).

16. Shula Radin, Sylvie Falaize, Mark, H. Lee and Paul Ducheyne, In vitro bioactivity and degradation behavior of silica xerogel intended as controlled release materials. Biomaterials, 23, 3113-3122 (2002).

17. Marivalda, M. Pereira, and Larry L. Hench, Mechanisms of hydroxyapatite formation on porous gel-silica substrate. Journal of Sol-Gel Science and Technology, 7, 59-68 (1996).

Received 11/11/2012; accepted 28/11/2012)

Egypt. J. Chem. 55, No. 4 (2012) 


\section{تحضير السليكا النا نومترية النشطة بيولوجيا من سليكات الصوديوم}

سحر الخولى و دعاء محمد المكاوى

قسم الكيمياء الفيزيائية ـ المركز القومي للبحوث ــ ـ القاهرة- مصر

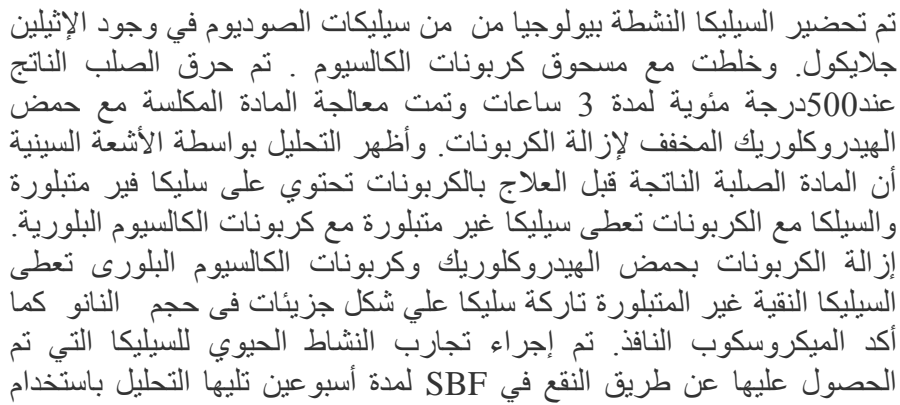

.EDX, SEM 